\title{
Do Professional Soccer Players have a Vitamin D Status Supporting Optimal Performance in Winter time?
}

Vander Slagmolen $\mathbf{G}^{1}$, van Hellemondt $\mathrm{FJ}^{1}$ and Wielders $\mathrm{JPM}^{2^{*}}$

${ }^{1}$ Department of Sports Medicine, Meander Medical Center, Amersfoort, the Netherlands

${ }^{2}$ Department of Clinical Chemistry, Meander Medical Center, Amersfoort, the Netherlands

"Corresponding author: Wielders JPM, Department of Clinical Chemistry, Meander Medical Center, Amersfoort, the Netherlands, Tel: 31338502083; Email:jpm.wielders@meandermc.nl

Received date: March 20, 2014; Accepted date: April 21, 2014; Published date: April 30, 2014

Copyright: ( 2014 VanderSG, et al. This is an open-access article distributed under the terms of the Creative Commons Attribution License, which permits unrestricted use, distribution, and reproduction in any medium, provided the original author and source are credited.

\begin{abstract}
Background: Vitamin $\mathrm{D}$ is well known for its role in calcium homeostasis and bone metabolism. In addition 25 $(\mathrm{OH})$ vitamin D3 (25OHD3) deficiency is correlated with muscle pain and weakness, hence there is increasing interest in optimal 25OHD3 levels for athletes. We investigated the prevalence of 25OHD3 deficiency and the ethnical variation in $25(\mathrm{OH}) \mathrm{D}$ concentrations among professional soccer players in the winter season.
\end{abstract}

Methods: Cross-sectional survey of 87 professional soccer players (aged 18-35) from one Belgian and two Dutch first division soccer clubs. Blood samples were collected from October 2009 till March 2010. 25OHD3 was measured using an electro-chemiluminescence immunoassay (Roche), reference interval: 50-130 nmol/L.

Results: For 47 players $(54 \%)$ of the total group the $250 \mathrm{HD} 3$ was $<50 \mathrm{nmol} / \mathrm{L}$. For 16 subjects $(18.4 \%)$ concentrations $<30 \mathrm{nmol} / \mathrm{L}$ were found. All black players $(n=20)$ had blood levels $<50 \mathrm{nmol} / \mathrm{L}$ and $9 / 20<30 \mathrm{nmol} / \mathrm{L}$. In Latin-American players 10 out of 15 had $25 \mathrm{OHD} 3<50 \mathrm{nmol} / \mathrm{L}$ and $5 / 15<30 \mathrm{nmol} / \mathrm{L}$. For Caucasian players, 21/52 players were $<50 \mathrm{nmol} / \mathrm{L}$ and $2 / 52<30 \mathrm{nmol} / \mathrm{L}$.

Conclusion: The vitamin $\mathrm{D}$ level in professional soccer players at the end of the summer and during the winter season in West-Europe is obvious below optimal, for Caucasians $40 \%$ were deficient $(<50 \mathrm{nmol} / \mathrm{L})$, but all black athletes were deficient or severely deficient $(<30 \mathrm{nmol} / \mathrm{L})$. Especially dark skinned soccer players, as well as other athletes may improve their physical performance by keeping their $25 \mathrm{OHD} 3$ level above $75 \mathrm{nmol} / \mathrm{L}$ all year round.

Keywords: Professional soccer players; Vitamin D; Deficiency; Cross sectional survey

\section{Introduction}

Unlike other vitamins, the main part of our needs for vitamin D is produced by exposure of our skin to sunlight. Clothing, indoor sports activities, use of sun screen or a darker skin tone limits the dermal synthesis of vitamin D. Furthermore it is known for 25(OH)D levels to have a seasonal variation due to insufficient ultraviolet (UV) B radiation from November till April at around $52^{\circ}$ northern latitude [1].

Vitamin D deficiency leads to muscle pain and weakness [2], and hence it has been suggested that for optimal performance and endurance for athletes their vitamin D status should be optimal. So measuring the atlethe's vitamin D level is desirable. Recent studies suggested a vitamin D deficiency in indoor athletes [3] and middleeastern sportsmen [4], on the contrary outdoor cyclists had an adequate vitamin D level [5].

In our study, we evaluated the $25(\mathrm{OH}) \mathrm{D}$ status in Dutch and Belgian soccer players in autumn and winter, since the soccer season starts in August and ends in May. Furthermore we examined ethnicity as confounder of vitamin D levels.

\section{Methods}

We conducted a cross-sectional survey of 87 professional soccer players (aged 18-35) in four soccer teams from one Belgian and two Dutch first division soccer clubs (two teams from one of the Dutch clubs). Blood samples were collected from October 2009 until March 2010. Three athletes were excluded because they were absent the day of the blood sampling due to injury. Data were collected on age, selfdeclared ethnicity, training hours (usually in the morning), multivitamin use, height and weight. All athletes had undergone a routine pre-season physical examination by their team physician and were considered in good health. All participants gave their informed consent.

The soccer stadiums are situated in Brussels, Belgium at latitude $50.5^{\circ} \mathrm{N}$ and Amsterdam or Utrecht in The Netherlands at latitude $52.2^{\circ} \mathrm{N}$ and $52.5^{\circ} \mathrm{N}$, respectively. The $25 \mathrm{OHD} 3$ was measured using by the ROCHE method at that time (electro-chemiluminescence immunoassay using the polyclonal antibody), having an inter-assay $\mathrm{CV}$ of $6.9 \%$ at $25.5 \mathrm{nmol} / \mathrm{L} 25(\mathrm{OH})$-vitamin $\mathrm{D} 3$ and $3.2 \%$ at 72.5 $\mathrm{nmol} / \mathrm{L}$.

The reference interval is $50-130 \mathrm{nmol} / \mathrm{l}$, we consider levels below 30 $\mathrm{nmol} / \mathrm{l}$ as severe deficient. 
Citation: Vander SG, van Hellemondt FJ, Wielders JPM (2014) Do Professional Soccer Players have a Vitamin D Status Supporting Optimal Performance in Winter time?. J Sports Med Doping Stud 4: 138. doi:10.4172/2161-0673.1000138

Page 2 of 3

\section{Results}

Demographic characteristics of our study group are presented in Table 1. The reported use by 20 players of vitamin D3 (in multivitamins) intake was $2 \mu \mathrm{g} /$ day $(80 \mathrm{iU})$, which is considered neglectable.

\begin{tabular}{|l|l|}
\hline Demographic Chatactezistics & $\begin{array}{l}\text { Subjects } \\
\text { (n=87) }\end{array}$ \\
\hline Age (years) & $25 \pm 4$ \\
\hline Sex (male) & 87 \\
\hline BMI (Kg/m $\left.{ }^{2}\right)$ & $23.2 \pm 2.0$ \\
\hline Ethnicity Caucasian & 52 \\
\hline African American & 20 \\
\hline Latin-American & 15 \\
\hline Physical activity (hours/week) & 12 \\
\hline Multivitamin & \\
\hline Yes & 20 \\
\hline No & 67 \\
\hline Recent visit sunny country & \\
\hline Yes & 2 \\
\hline No & 85 \\
\hline
\end{tabular}

Table 1: Characteristics of study subjects (data are presented as means \pm standard deviation or absolute figures)

Results split up for the teams and the actual sampling month are given in figure 1 . The $25(\mathrm{OH}) \mathrm{D}$ concentration changed significantly across time and averaged $53.8 \pm 18.1 \mathrm{nmol} / \mathrm{L}$ in October and $31.2 \pm$ $14.4 \mathrm{nmol} / \mathrm{L}$ in March. In 47 subjects $(54 \%)$ a 25(OH)D3 level below $50 \mathrm{nmol} / \mathrm{L}$ was found and in 16 athletes $(18 \%)$ the $25(\mathrm{OH}) \mathrm{D} 3$ was $<30$ $\mathrm{nmol} / \mathrm{L}$.

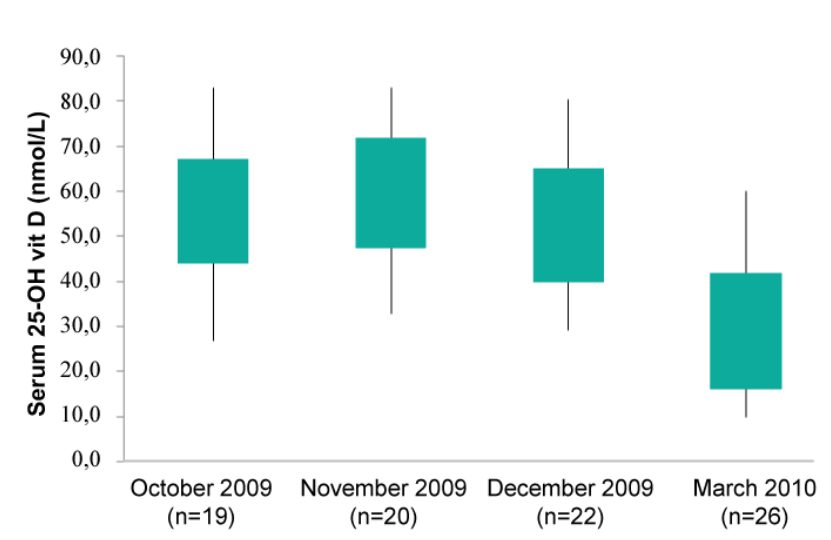

Figure 1: Box plot of the 25(OH)D measurements in four teams

As shown in Figure 2, the vitamin $\mathrm{D}$ concentrations were consistently lower for the black athletes $(n=20)$ : all of them had levels
$<50 \mathrm{nmol} / \mathrm{L}$ and in 9/20 we found a severe deficiency (level $<30$ $\mathrm{nmol} / \mathrm{L})$. Of the Latin-American athletes $67 \%$ had a $25(\mathrm{OH}) \mathrm{D} 3$ values $<50 \mathrm{nmol} / \mathrm{L}$ and $5 / 15(33 \%)<30 \mathrm{nmol} / \mathrm{L}$. Among the Caucasians, $17 / 52$ players (33\%) had a vitamin D deficiency at $50 \mathrm{nmol} / \mathrm{L}$ and $2 / 52$ $(4 \%)$ a severe deficiency.

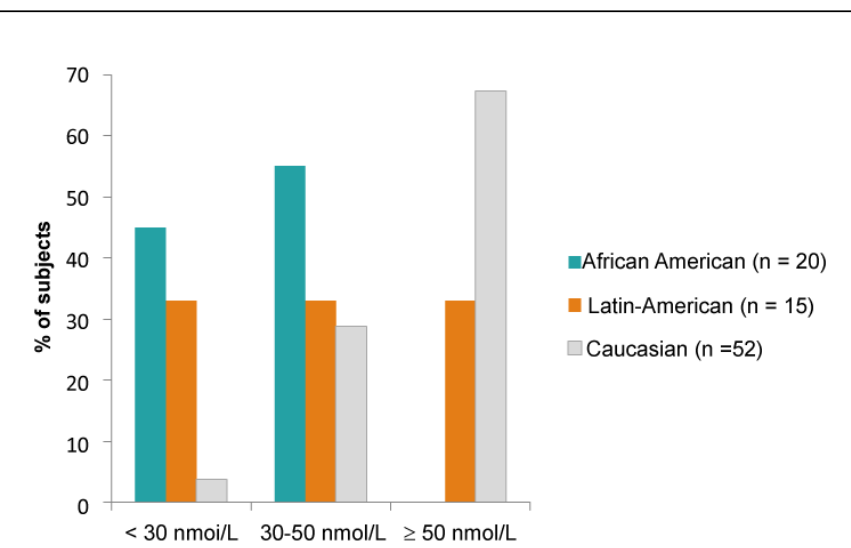

Figure 2: Vitamin D deficiency (\% of subjects) according to ethnicity

\section{Discussion}

The prevalence of 25OHD3 deficiency in professional soccer players was rather high for subjects spending much time outdoors, even shortly after the summer season. For comparison, the prevalence of deficiency $(<50 \mathrm{nmol} / \mathrm{l} 25 \mathrm{OHD} 3)$ in a Caucasian Dutch population is about $23 \%$ in summertime [6]. The 25OHD3 level decreases in wintertime as expected, since on our latitude UV radiation is insufficient for vitamin D formation in the skin from November up till and including March [1].

Galan et al. studied 28 Spanish football players and found $64 \%$ below $75 \mathrm{nmol} / \mathrm{L}$ in February [7]. In a study by Morton of 20 Premier League soccer players, 18 Caucasians, showed a similar decrease in vitamin D status in December [8], however they did not measure the nadir that will be reached in March as we showed. The disadvantage of high melanin content in the dark skinned soccer players at our latitude, may be in combination with life-style and diet, is clearly illustrated in our study by the deficiency of all black athletes $(25 \mathrm{OHD} 3<50 \mathrm{nmol} / \mathrm{L})$.

What effects of vitamin D deficiency may be of interest for athletes and coaches? Angeline et al. found in 89 players from an American team that those who suffered from muscle injuries had a significantly lower vitamin D level than the uninjured players [9]. Similar results were reported of beneficial effects on muscular performance and injury occurrence in elite ballet dancers [10]. Further, when patients suffering from chronic kidney failure (with or without the need for dialysis) were supplemented with vitamin $\mathrm{D}$ an improvement of muscle strength, functional ability and balance was observed [11]. Muscle strength and performance for elderly was reported to be best for levels $>75 \mathrm{nmol} / \mathrm{L}$ [12].

Possible explanations of the role of vitamin D in muscle function and metabolism has recently been discussed in a review [2]. Very recently the beneficial effect of vitamin $\mathrm{D}$ on oxidative 
Citation: Vander SG, van Hellemondt FJ, Wielders JPM (2014) Do Professional Soccer Players have a Vitamin D Status Supporting Optimal Performance in Winter time?. J Sports Med Doping Stud 4: 138. doi:10.4172/2161-0673.1000138

Page 3 of 3

phosphorylation was shown, giving a clue for the possible mechanism of vitamin D associated fatigue and muscle weakness [13].

What could be an optimal level for athletes? Studies on physical performance improvement by vitamin $\mathrm{D}$ suppletion most often do not present the initial status, the most significant improvements are seen especially when the baseline level was below $25 \mathrm{nmol} / \mathrm{l}[2]$. However athletes need and search for optimal performance. We suggest that especially dark skinned athletes, may improve their performance by keeping their 25OHD3 level above $75 \mathrm{nmol} / \mathrm{L}$ all year round. To maintain a $75 \mathrm{nmol} / \mathrm{l}$ level in wintertime, an end of summer level of approximately $125 \mathrm{nmol} / \mathrm{l}$ has been suggested $[7,14]$ or a suppletion with 1000-2000 iU/day, depending on the original base line level [15].

For soccer players with severe vitamin D deficiency (levels below 25 $\mathrm{nmol} / \mathrm{l}$ ) suppletion will lead to substantial endurance improvement For soccer players with vitamin D mild deficiency (levels 25-50 $\mathrm{nmol} / \mathrm{l}$ ) smaller effects are to be expected after suppletion. For optimal physical performance $25 \mathrm{OH}$ vitamin D3 levels of 75-125 nmol/l have been advised [16]. We found $130 \mathrm{nmol} / \mathrm{l}$ being the upper level of the reference interval for Caucasians in Dutch summers.

More research is needed on the musculoskeletal effect of vitamin D in healthy athletes and on fine-tuning the level of serum 25OHD3 corresponding with optimal physical performance and endurance.

\section{Conclusion}

Especially for athletes an optimal condition of their muscles is an essential for top performance in all seasons. We showed that the vitamin $\mathrm{D}$ level in professional soccer players in West-Europe, during the winter season is far below optimal, especially in dark players. Supplementation may improve their performance and endurance.

\section{Acknowledgments}

\section{References}

1. Holick MF (2007) Vitamin D deficiency. N Engl J Med 357: 266-281.

2. Girgis CM, Clifton-Bligh RJ, Hamrick MW, Holick MF, Gunton JE (2013) The roles of vitamin D in skeletal muscle: form, function, and metabolism. Endocr Rev 34: 33-83.
3. Lovell G (2008) Vitamin D status of females in an elite gymnastics program. Clin J Sport Med 18: 159-161.

4. Hamilton B, Grantham J, Racinais S, Chalabi H (2010) Vitamin D deficiency is endemic in Middle Eastern sportsmen. Public Health Nutr 13: 1528-1534.

5. Willis KS, Peterson NJ, Larson-Meyer DE (2008) Should we be concerned about the vitamin D status of athletes? Int J Sport NutrExercMetab 18: 204-224.

6. van der Meer IM, Boeke AJ, Lips P, Grootjans-Geerts I, Wuister JD, et al. (2008) Fatty fish and supplements are the greatest modifiable contributors to the serum 25-hydroxyvitamin $\mathrm{D}$ concentration in a multiethnic population. ClinEndocrinol (Oxf) 68: 466-472.

7. Galan F, Ribas J, Sánchez-Martinez PM, Calero T, Sánchez AB, et al. (2012) Serum 25-hydroxyvitamin D in early autumn to ensure vitamin D sufficiency in mid-winter in professional football players. ClinNutr 31: 132-136.

8. Morton JP, Iqbal Z, Drust B, Burgess D, Close GL, et al. (2012) Seasonal variation in vitamin $D$ status in professional soccer players of the English Premier League. ApplPhysiolNutrMetab 37: 798-802.

9. Angeline ME, Gee AO, Shindle M, Warren RF, Rodeo SA (2013) The effects of vitamin D deficiency in athletes. Am J Sports Med 41: 461-464.

10. Wyon MA, Koutedakis Y2, Wolman R3, Nevill AM4, Allen N5 (2014) The influence of winter vitamin D supplementation on muscle function and injury occurrence in elite ballet dancers: a controlled study. J Sci Med Sport 17: 8-12.

11. Taskapan H, Baysal O, Karahan D, Durmus B, Altay Z, et al. (2011) Vitamin D and muscle strength, functional ability and balance in peritoneal dialysis patients with vitamin D deficiency. ClinNephrol 76: $110-116$.

12. Wicherts IS, van Schoor NM, Boeke AJ, Visser M, Deeg DJ, et al. (2007) Vitamin D status predicts physical performance and its decline in older persons. J ClinEndocrinolMetab 92: 2058-2065.

13. Sinha A, Hollingsworth KG, Ball S, Cheetham T (2013) Improving the vitamin $\mathrm{D}$ status of vitamin $\mathrm{D}$ deficient adults is associated with improved mitochondrial oxidative function in skeletal muscle. J ClinEndocrinolMetab 98: E509-513.

14. Barger-Lux MJ, Heaney RP (2002) Effects of above average summer sun exposure on serum 25-hydroxyvitamin D and calcium absorption. J ClinEndocrinolMetab 87: 4952-4956.

15. Heaney RP (2005) The Vitamin D requirement in health and disease. J Steroid BiochemMolBiol 97: 13-19.

16. Shuler FD, Wingate MK, Moore GH, Giangarra C (2012) Sports Health Benefits of Vitamin D. Sports Health 4: 496-501. 